\title{
GRAIN QUALITY OF UPLAND RICE CULTIVARS IN RESPONSE TO CROPPING SYSTEMS IN THE BRAZILIAN TROPICAL SAVANNA
}

\author{
Carlos Alexandre Costa Crusciol ${ }^{1 *}$; Orivaldo Arf ${ }^{2}$; Rogério Peres Soratto ${ }^{1}$; Gustavo Pavan \\ Mateus $^{3}$ \\ IUNESP/FCA - Depto. de Produção Vegetal, Fazenda Experimental Lageado, C.P. 237 - 18603-970 - Botucatu, \\ $S P$ - Brasil. \\ ${ }^{2}$ UNESP/FE - Depto. de Fitotecnia, Tecnologia de Alimentos e Sócio-Economia, C.P. 31 - 15385-000 - Ilha \\ Solteira, SP - Brasil. \\ ${ }^{3}$ APTA - Pólo Regional de Desenvolvimento Tecnológico dos Agronegócios do Extremo Oeste, C.P. 67 - \\ 16900-000 - Andradina, SP - Brasil. \\ *Corresponding author 〈crusciol@fca.unesp.br>
}

\begin{abstract}
The industrial quality of grain is an important parameter to determine the commercial value of rice and can be influenced by water availability and type of cultivar. The present study aimed to evaluate the milling yield as well as the protein and nutrient contents of polished grains originated from two upland rice cultivars grown under rainfed and sprinkler-irrigated conditions. A randomized block design was used in a split-plot arrangement with eight replicates. Plots consisted of two cropping systems (rainfed and sprinkler-irrigated) with subplots consisting of two cultivars recommended for upland ecosystems (IAC 201 and Carajás). The sprinkler irrigation system increased upland rice milling $(8.0 \%)$ and head rice yield (23.7\%), for years with hot and dry weather spells occurring during the reproductive and maturation stages. Under conditions of lower water availability, the Carajás cultivar showed a milled yield value 5.1\% higher than that of cultivar IAC 201. Lower water availability provided increases in protein, $\mathrm{N}, \mathrm{P}, \mathrm{Ca}, \mathrm{Mg}, \mathrm{Fe}$, and $\mathrm{Zn}$ contents but reductions in $\mathrm{S}$ and $\mathrm{Cu}$ in the polished grains. Cultivars IAC 201 and Carajás had similar nutrient contents in the polished grains. Key words: Oryza sativa, sprinkler irrigation, milling yield, head rice yield
\end{abstract}

\section{QUALIDADE DE GRÃOS DE CULTIVARES DE ARROZ DE TERRAS ALTAS EM FUNÇÃO DO SISTEMA DE CULTIVO NA REGIÃO DO CERRADOBRASILEIRO}

\begin{abstract}
RESUMO: A qualidade industrial do grão beneficiado é parâmetro importante para determinar o valor de comercialização do arroz e pode estar relacionada com a disponibilidade hídrica e o cultivar utilizado. O trabalho teve como objetivo avaliar o rendimento de engenho e teores de nutrientes e proteínas nos grãos brunidos provenientes de dois cultivares de arroz de terras altas conduzidos sob condições de sequeiro e irrigados por aspersão. O delineamento experimental utilizado foi o de blocos ao acaso, em esquema de parcela subdividida, com oito repetições. As parcelas foram constituídas por dois sistemas de cultivo (sequeiro e irrigado por aspersão) e as subparcelas por dois cultivares indicados para o ecossistema de terras altas (IAC 201 e Carajás). A irrigação por aspersão aumentou o rendimento de engenho $(8,0 \%)$ e de grãos inteiros $(23,7 \%)$ do arroz de terras altas, em anos com ocorrência de veranicos nas fases reprodutiva e de maturação. Sob condições de baixa disponibilidade hídrica o cultivar Carajás apresenta rendimento de benefício 5,1\% maior do que o cultivar IAC 201. A baixa disponibilidade hídrica promove acréscimo nos teores de proteína, $\mathrm{N}, \mathrm{P}, \mathrm{Ca}, \mathrm{Mg}, \mathrm{Fe}$ e $\mathrm{Zn}$ nos grãos brunidos, porém reduz os teores de $\mathrm{S}$ e $\mathrm{Cu}$. Os teores de nutrientes nos grãos brunidos dos cultivares IAC 201 e Carajás são similares.

Palavras-chave: Oryza sativa, irrigação por aspersão, rendimento de benefício, rendimento de grãos inteiros
\end{abstract}

\section{INTRODUCTION}

In addition to low yield, upland rice grown un- der the dryland system in general presents lower grain quality when compared to grains originating from lowland systems. A major reason for this, aside from 
causes due to genetic variability, is the frequent periods of water deficiency the plant is exposed to during the cycle, in highly productive regions (Crusciol et al., 1999b).

The presence of broken grains in a rice lot is an undesirable characteristic, since it decreases quality and economic value, and also leads to a reduction of the milling yield since small grains may be thrown away along with the hulls (Crusciol et al., 1999a). Grain breakage, verified during the milling process, is caused by cracks or weaker regions in the grains, and occurs especially during the hulling process and when the grains are polished (Crusciol et al., 1999b). Variety traits, inadequate crop management as well as weather conditions (temperature, humidity, and precipitation) may influence milling yield and broken-grain ratio, decreasing the product's physical quality (Chen \& Kunze, 1983; Srinivas \& Bhashyam, 1985).

Besides representing a means of minimizing crop loss risk and improving productivity in upland ecosystems, sprinkler irrigation may also allow higher quality grains to be obtained, since the grain filling process is continuous, leading to higher head rice and threshed-grain yields, consequently reducing brokengrain yield (Oliveira, 1994), especially in years with the occurrence of hot and dry weather spells (Rodrigues, 1998; Arf et al., 2002). In addition, rice nutritional quality is also strongly influenced by the environment.

In the context of sprinkler-irrigated crop systems, information is still scarce regarding upland-rice grain-nutrient content and industrial quality. Therefore, the present work aimed to evaluate milling yield and protein and nutrient contents in polished grains of cultivars IAC 201 and Carajás under rainfed and sprinkler-irrigated conditions.

\section{MATERIALAND METHODS}

This work was performed under field and laboratory conditions, where grains from experiments carried out in field conditions were used, in the cropping seasons of 1994/95 and 1995/96 in Selvíria State of Mato Grosso do Sul, Brazil $\left(51^{\circ} 22^{\prime} \mathrm{W}, 20^{\circ} 22^{\prime} \mathrm{S}\right.$, at altitude $335 \mathrm{~m}$ ). The chemical characteristics of the clayey-textured Typic Haplustox at the experiment site (Table 1) were established before the experiment, ac- cording to the methodology proposed by Raij \& Quaggio (1983). The mean annual rain precipitation is $1,370 \mathrm{~mm}$, the mean annual temperature is $23.5^{\circ} \mathrm{C}$ and the relative air humidity ranges from 70 to $80 \%$.

A randomized complete block design, in a split-plot scheme and eight replications was used. Plots consisted of two cultivation systems (rainfed and sprinkler-irrigated) with subplots consisting of two cultivars recommended for upland ecosystems (IAC 201 and Carajás). The distance between plots was 8 $\mathrm{m}$. Each subplot consisted of six rows of plants, six meter length, spaced $0.40 \mathrm{~m}$ between rows. Only the four central rows were usable areas, whereas $0.50 \mathrm{~m}$ of the edge of each row of plants and the two outer rows were considered border.

IAC 201 cultivar in the state of Mato Grosso do Sul presents the following primary characteristics: medium size, precocious cycle, long and slender grain type, translucent and high-yield whole grains in milling with an insignificant chalk and outstanding culinary qualities. Carajás cultivar shows size and cycle similar to IAC 201 cultivar, although it shows better plant architecture, higher finishing and water deficiency tolerance and long grain type (Bazoni et al., 1995).

During the experiment, the minimum and maximum air temperatures were daily determined at the weather station, $500 \mathrm{~m}$ distant from the experimental location. The rainfall was determined with a Ville de Paris raingange installed at the center of the experimental area. Weather elements are shown in Figure 1. In order to establish treatments under sprinkler irrigation, the available water capacity (AWC), in mm was determined by the following equation: $\mathrm{AWC}=[(\mathrm{FC}-$ WPP)/100].d.h, where FC is the field capacity (\%); WPP is the wilt permanent point (\%); $\mathrm{d}$ is the soil density $\left(1,250 \mathrm{~kg} \mathrm{~m}^{-3}\right) ; \mathrm{h}$ is the rooting effective depth $(0.20 \mathrm{~m})$. In this way, the employed AWC of the soil was established as $14.80 \mathrm{~mm}$.

In sprinkler-irrigated treatments, the water supply was conveyed by a fixed conventional sprinkler system, with outflow of $3.3 \mathrm{~mm}$ hour $^{-1}$. The irrigations were performed every time the crop maximum evapotranspiration $(\mathrm{ETm})$ reached $8.25 \mathrm{~mm}$, in other words, $45 \%$ of the AWC. The ETm was estimated from the equation: $\mathrm{ETm}=\mathrm{Kc}$.ETo; where ETm =

Table 1 - Soil chemical characteristics for depth from 0 to $0.20 \mathrm{~m}$. Selvíria, Mato Grosso do Sul state, Brazil.

\begin{tabular}{|c|c|c|c|c|c|c|c|c|c|}
\hline Year & O.M. & $\mathrm{pH}^{1}$ & $\mathrm{P}^{2}$ & K & $\mathrm{Ca}$ & $\mathrm{Mg}$ & $\mathrm{H}+\mathrm{Al}$ & CEC & V \\
\hline & $\mathrm{g} \mathrm{kg}^{-1}$ & & $\mathrm{mg} \mathrm{dm}^{-3}$ & - - - - & 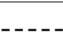 & $\mathrm{nol}_{\mathrm{c}} \mathrm{d}$ & 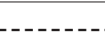 & -.-.- & $\%$ \\
\hline $1994 / 95$ & 26 & 5.4 & 24 & 1.3 & 24 & 15 & 29 & 69.3 & 58 \\
\hline $1995 / 96$ & 23 & 5.1 & 26 & 1.9 & 28 & 8 & 28 & 65.9 & 58 \\
\hline
\end{tabular}

${ }^{1}$ Determined in a $0.01 \mathrm{~mol}^{-1} \mathrm{Cacl}_{2}$ solution. ${ }^{2}$ Extracted by resin. 
crop's maximum evapotranspiration $\left(\mathrm{mm} \mathrm{day}^{-1}\right)$, ETo $=$ reference evapotranspiration $\left(\mathrm{mm} \mathrm{day}^{-1}\right)$ and $\mathrm{Kc}=$ crop coefficient.

The water evaporation ( $\mathrm{mm}$ ) was daily obtained from a Class A pan. The Class A pan coefficient (Kp) was the one proposed by Doorenbos \& Pruitt (1976), calculated according to the surrounding area, wind speed and relative humidity. Different $\mathrm{Kc}$ values were employed in the different crop development periods, according to Reichardt (1987): 0.4 for the period between the emergence and 30 days before flowering; 0.7 for the period from 30 to 19 days before flowering; 1.0 between 19 and 11 days before

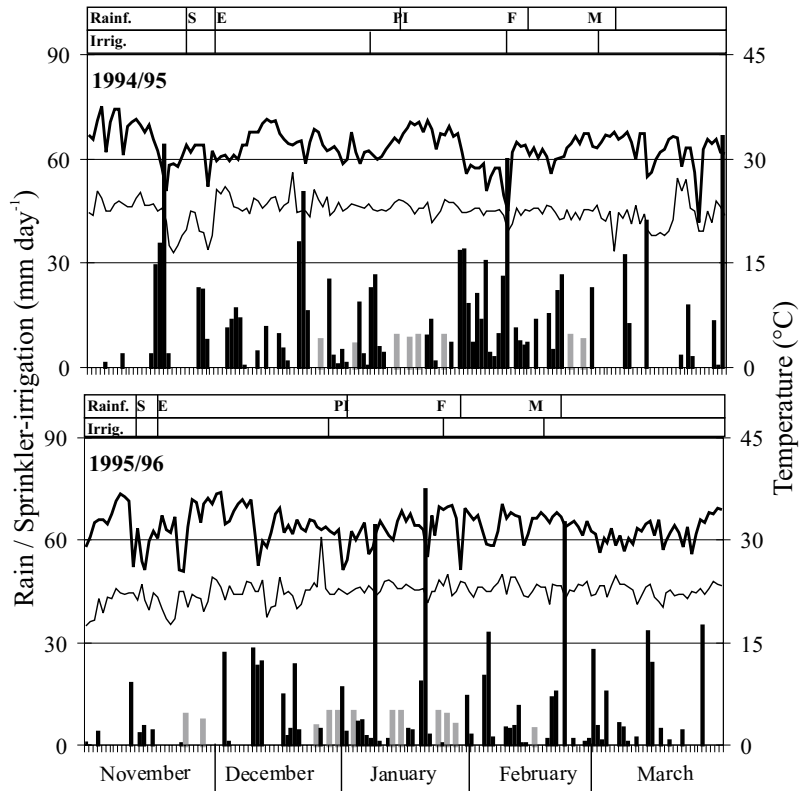

Figure 1 - Rain (|), sprinkler-irrigation ( | ), maximum and minimum temperatures $(-)$ obtained for the experimental area during the period from November to March in the 1994/95 and 1995/96 cropping seasons at Selvíria, Mato Grosso do Sul state, Brazil. Rainf.: treatment without irrigation, receiving only natural precipitation; Irrig.: sprinkler-irrigated system; S: sowing; E: emergence; PI: panicle initiation; F: flowering and $\mathrm{M}$ : maturation. flowering; 1.3 for the period 11 to three days before flowering; 1.0 for the period from three days to five days after flowering; and 0.7 for the period between five and 12 days after flowering. The amount and distribution of the water received by the rice crop are shown in Table 2.

Soil was tilled and two leveling disks employed, the first one soon after the soil tilling and the second shortly before the sowing. The mineral fertilization, during the two cropping seasons, was made by applying into the sowing furrow using $12 \mathrm{~kg} \mathrm{ha}^{-1}$ of $\mathrm{N}$, $90 \mathrm{~kg} \mathrm{ha}^{-1}$ of $\mathrm{P}_{2} \mathrm{O}_{5}, 30 \mathrm{~kg} \mathrm{ha}^{-1}$ of $\mathrm{K}_{2} \mathrm{O}$ (formula NPK 04-30-10) and $40 \mathrm{~kg} \mathrm{ha}^{-1}$ of FTE BR-12 as source of nutrients $(2.17 \% \mathrm{~B}, 9.2 \% \mathrm{Zn}, 0.8 \% \mathrm{Cu}, 3.82 \% \mathrm{Fe}$, $3.47 \% \mathrm{Mn}$ and $0.132 \% \mathrm{Mo})$. Sowings were completed on 24 November 1994 and 13 November 1995, at the density of 100 viable seeds per square meter. Also 1.5 $\mathrm{kg} \mathrm{ha}^{-1}$ of carbofuran $5 \mathrm{G}$ (a.i.) was added into the sowing furrow to control termites (Synterms molestus, Procorniterms striatus and Cornitermes lespesii) and elasmo caterpillars (Elasmopalpus lignosellus). The emergence of plants occurred on 02 December 1994 and 21 November 1995, respectively. Weed control was accomplished with oxadiazon $\left(1 \mathrm{~kg} \mathrm{ha}^{-1}\right.$ a.i. $)$ herbicide in the pre-emergence, one day after the sowing and 2.4D (670 $\mathrm{g} \mathrm{ha}^{-1}$ a.i.) in the post-emergence. Nitrogen sidedressing was performed at tillering, with 30 $\mathrm{kg} \mathrm{ha}^{-1}$ of $\mathrm{N}$ urea source.

When approximately $90 \%$ of panicles had grains of typical mature coloration, manual harvest was carried out. Panicles were left to dry in the sun for one or two days and later submitted to mechanical threshing in a research plot thresher.

From each subplot, one sample of $100 \mathrm{~g}$ of hulled rice grains was collected, and a (SUZUKI) proof mill model MT was used for 1 minute; then the polished grains were weighed and the found values were considered the milling yield percentage. Later, the polished grains were placed in a "trieur" 2 and the grains separated for 30 seconds. The grains that remained in

Table 2 - Amount and distribution of water received by upland rice crops ( $\mathrm{mm}$ ) and crop stage duration (days) under rainfed and sprinkler-irrigated systems. Selvíria, Mato Grosso do Sul state, Brazil.

\begin{tabular}{lllll}
\hline \multirow{2}{*}{ Cropping system } & \multicolumn{3}{c}{ Crop stages } & \multirow{2}{*}{ Total } \\
\cline { 2 - 4 } & Vegetative & Reproductive & Maturation & \\
\cline { 2 - 4 } Rainfed & \multicolumn{3}{c}{$1994 / 95$} \\
Sprinkler-irrigated & $333.7(47)^{(1)}$ & $343.9(30)$ & $135.4(20)$ & $813.0(97)$ \\
\hline & $293.3(39)$ & $322.6(30)$ & $233.6(24)$ & $849.5(93)$ \\
\hline Rainfed & & & $1995 / 96$ & $598.8(98)$ \\
Sprinkler-irrigated & $245.2(46)$ & $228.4(30)$ & $124.2(22)$ & $687.8(92)$ \\
\hline
\end{tabular}

${ }^{(1)}$ Values in parentheses are crop stage duration in days. 
the "trieur" were weighed to determine percentages of head rice yield and broken grains.

In 1995/96, the polished grains were dried in an oven at $105^{\circ} \mathrm{C}$, after which grains milling were ground (to pass a 40-mesh stainless steel screen) and subjected to nutrient content determinations. Nitrogen was analyzed by acid sulfuric digestion and later quantification by semi-micro-Kjeldahl method (Bataglia et al., 1983). Analyses of $\mathrm{P}, \mathrm{K}, \mathrm{Ca}, \mathrm{Mg}, \mathrm{S}, \mathrm{Fe}, \mathrm{Zn}, \mathrm{Cu}$, and $\mathrm{Mn}$ contents were performed following to nitricperchloric acid digestion (Bataglia et al., 1983). Polished-grain protein content was calculated by multiplying the nitrogen content by the factor 5.95.

Data were submitted to analysis of variance and the means compared by LSD $(p \leq 0.05)$ test.

\section{RESULTS AND DISCUSSION}

During the first cropping season, milled grain yield was influenced by cropping system and cultivar as well as by the interaction between these factors $(p \leq 0.05)$ (Table 3). Based on partitioned interaction observations (Table 4), it was verified that under rainfed conditions the Carajás cultivar showed a milled yield value $5.1 \%$ higher than that of cultivar IAC 201, corroborating Oliveira (1994) and Crusciol (1998), who verified a contrasting performance of those cultivars in terms of response to sprinkler irrigation. The lower tolerance to water deficit shown by the IAC 201 cultivar can be explained by the fact that this cultivar originated from a cross between cultivar IAC 165 (recommended for upland crops) and cultivar Labelle (recommended for deepwater rice crops) (Arf et al., 2002). Sprinkler irrigation provided higher milling yields in both cultivars, both during the 1994/95 cropping season and the following year, indicating that water supplied through sprinkler irrigation may have pro- moted root growth, allowing better plant nutrition and grain filling, increasing milling yield, and allowing a continuous supply of water during periods when no precipitation was available (dry and hot weather spells, locally known as "veranicos"). Increased milling yields for all studied cultivars under sprinkler irrigation were also observed by Rodrigues (1998) and Arf et al. (2002).

Head rice yield indicates the weight of whole grains obtained after industrial processing. This is one of the most important parameters in rice commercial value determination (Arf et al., 2002). There was a cropping system effect on this characteristic only in the first year of the experiment $(p \leq 0.05)$ (Table 3). Sprinkler irrigation provided higher head rice yields in both cultivars. Therefore, adequate soil water availability enhances water and nutrient absorption as well as photosynthate translocation into the grains, allowing continuous grain filling and adequate development. Although water availability during the cycle was higher in the first year (Table 2), the occurrence of dry and hot weather spells, especially during the stage just before flowering and during the maturation stage (Figure 1), may have affected perfect grain development in the rainfed system, since the irrigation effect on grain development occurs, in some cases, well before that stage, promoting increased root growth and improved nutritional status, affecting grain filling dynamics. Rice chalkiness ratio and percentage of unfilled grains significantly increase when water deficits occur during the panicle emission and grain filling stages (Stermer, 1968). Well-developed grains show higher head rice yield, due to higher resistance to shocks and vibrations caused by harvest and industrial processing (Arf et al., 2002). The cultivars showed similar head rice yield values, though these may vary due to genetic characteristics (Chen \& Kunze, 1983; Srinivas \& Bhashyam, 1985).

Table 3 - Total milled rice yield, head rice yield and broken grains obtained from upland rice cultivars grown under rainfed and sprinkler-irrigated systems. Selvíria, Mato Grosso do Sul state, Brazil.

\begin{tabular}{|c|c|c|c|c|c|c|}
\hline \multirow{2}{*}{ Treatments } & \multicolumn{2}{|c|}{ Total milled rice } & \multicolumn{2}{|c|}{ Head rice } & \multicolumn{2}{|c|}{ Broken grains } \\
\hline & $1994 / 95$ & $1995 / 96$ & $1994 / 95$ & $1995 / 96$ & $1994 / 95$ & $1995 / 96$ \\
\hline & n & (n- & - & (n) & - & (-...... \\
\hline \multicolumn{7}{|l|}{ Cropping system } \\
\hline Rainfed & $63.9 \mathrm{~b}^{(1)}$ & $67.9 \mathrm{~b}$ & $38.8 \mathrm{~b}$ & 45.1 & 25.1 & 22.8 \\
\hline Sprinkler-irrigated & $69.0 \mathrm{a}$ & $69.0 \mathrm{a}$ & $48.0 \mathrm{a}$ & 46.6 & 21.1 & 22.1 \\
\hline CV (\%) & 4.8 & 0.9 & 22.1 & 11.3 & 32.0 & 21.4 \\
\hline \multicolumn{7}{|l|}{ Cultivar } \\
\hline IAC 201 & 65.6 & 68.4 & 44.8 & 45.4 & $20.9 \mathrm{~b}$ & 23.0 \\
\hline Carajás & 67.3 & 68.5 & 42.0 & 46.4 & $25.4 \mathrm{a}$ & 21.9 \\
\hline CV (\%) & 1.6 & 1.7 & 10.1 & 7.5 & 14.0 & 15.0 \\
\hline
\end{tabular}

${ }^{(1)}$ Means followed by different letters in the columns, for each factor, are different by the LSD test $(p \leq 0.05)$. 
Broken-grain yield was not influenced by cropping system in either experimental year $(p \leq 0.05)$ (Table 3). In the 1994/95 cropping season, cultivar IAC 201 presented lower broken-grain yield, a characteristic not influenced by cultivar in the second cropping year.

The variation in rice nutritional quality is mainly due to genetic characteristics of the cultivars and key environmental factors (soil and weather), and consequently is also influenced by irrigation (water availability) (Barbosa Filho \& Fonseca, 1994; Nanda \& Coffman, 1979). However, the rainfed treatments provided grains with increased protein, $\mathrm{N}, \mathrm{Ca}, \mathrm{Mg}, \mathrm{Fe}$, and $\mathrm{Zn}$ (Table 5), which may be explained by a dilution effect, since productivity was higher for sprinkler-irrigated $\left(3,727 \mathrm{~kg} \mathrm{ha}^{-1}\right)$ that in rainfed systems $\left(2,516 \mathrm{~kg} \mathrm{ha}^{-1}\right)$. Crusciol et al. (2003a; b) also verified smaller contents of those nutrients and protein in the polished grains of rice in sprinkler-irrigated system. Protein contents observed in this work are smaller than reported by Angladette (1969), however, larger than verified by Castro et al. (1999).

Sulphur and copper levels were higher for grains obtained from sprinkler-irrigated systems, probably due to the fact that such treatment provides

Table 4 - Cropping system versus cultivar interaction, partitioned from the analysis of variance for total milled rice (\%). 1994/95 cropping season.

\begin{tabular}{lll}
\hline \multirow{2}{*}{ Cropping system } & \multicolumn{2}{c}{ Cultivar } \\
\cline { 2 - 3 } & IAC 201 & Carajás \\
\hline Rainfed & $62.3 \mathrm{bB}^{(1)}$ & $65.5 \mathrm{bA}$ \\
Sprinkler-irrigated & $69.0 \mathrm{aA}$ & $69.0 \mathrm{aA}$ \\
\hline
\end{tabular}

${ }^{(1)}$ Means followed by the same lower case letter in the columns, and upper case letters in the rows are different by the LSD test $(p \leq 0.05)$. better conditions for nutrient absorption, especially during the grain filling stage. Similar results were verified by Crusciol et al. (2003a; b).

Posphurus content in polished grains was affected by cropping system and by the interaction between cropping system and cultivar (Table 5 and 6). The rainfed treatments provided grains with higher $\mathrm{P}$ levels for both cultivars (Table 6). However, under rainfed conditions, cultivar IAC 201 showed increased $\mathrm{P}$ in grains, similarly to the Carajás cultivar in sprinkler-irrigated treatments.

Nutrient and protein contents in polished grains were similar for both cultivars, having difference only for Mn content (Table 5). The protein content average in polished grains of studied cultivars was of $80.0 \mathrm{~g} \mathrm{~kg}^{-1}$. Frei \& Becker (2004), observed protein content in grains of upland rice cultivars ranging between 70 and $137 \mathrm{~g} \mathrm{~kg}^{-1}$ on a dry matter basis, with an average of $95 \mathrm{~g} \mathrm{~kg}^{-1}$, which is higher than the average of the high yielding varieties $\left(89 \mathrm{~g} \mathrm{~kg}^{-1}\right)$.

The higher Fe contents in grains are probably related to the soil type, which contains higher content of this element. Evaluating the polished grains of 286 genotypes of rice, Yang et al. (1998) verified great variation in the micronutrients contents, with the medium contents varying of 4.0 to $29.5 \mathrm{mg} \mathrm{kg}^{-1}$ of $\mathrm{Fe}$, 8.2 to $95.0 \mathrm{mg} \mathrm{kg}^{-1}$ of $\mathrm{Zn}, 2.5$ to $143.5 \mathrm{mg} \mathrm{kg}^{-1}$ of $\mathrm{Cu}$, and 9.0 to $30.5 \mathrm{mg} \mathrm{kg}^{-1}$ of $\mathrm{Mn}$.

Although the cropping systems affected the levels of some nutrients, they did not disagree with regard to the nutrient content sequence found in the polished portion. On average between cropping systems, upland rice polished grains produced the following relative nutrient levels, in increasing order: $\mathrm{N}>\mathrm{Ca}>\mathrm{P}>\mathrm{S} \geq \mathrm{K}>\mathrm{Mg}>\mathrm{Zn}>\mathrm{Fe}>\mathrm{Mn}>\mathrm{Cu}$, for both cultivars.

Table 5 - Nutrients and protein content in polished grains obtained from upland rice grown under rainfed and sprinklerirrigated systems. Selvíria, Mato Grosso do Sul state, Brazil.

\begin{tabular}{|c|c|c|c|c|c|c|c|c|c|c|c|}
\hline Treatments & Protein & $\mathrm{N}$ & $\mathrm{P}$ & $\mathrm{K}$ & $\mathrm{Ca}$ & $\mathrm{Mg}$ & $\mathrm{S}$ & $\mathrm{Fe}$ & $\mathrm{Zn}$ & $\mathrm{Cu}$ & $\mathrm{Mn}$ \\
\hline & $-\ldots-\ldots-$ & $-\cdots-\cdots$ & 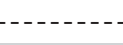 & $\mathrm{g} \mathrm{kg}^{-1}$ & $-\cdots--$ & $\ldots$ & - & - - - - - & $\ldots-\cdots m g$ & $\mathrm{gg}^{-1}-\ldots$ & - \\
\hline \multicolumn{12}{|l|}{ Cropping system } \\
\hline Rainfed & $84.5 \mathrm{a}^{(1)}$ & $14.2 \mathrm{a}$ & $1.28 \mathrm{a}$ & 0.48 & $4.8 \mathrm{a}$ & $0.48 \mathrm{a}$ & $0.39 \mathrm{~b}$ & $51.6 \mathrm{a}$ & $104.5 \mathrm{a}$ & $1.6 \mathrm{~b}$ & 6.8 \\
\hline Sprinkler-irrigated & $75.0 \mathrm{~b}$ & $12.6 \mathrm{~b}$ & $0.88 \mathrm{~b}$ & 0.55 & $3.5 \mathrm{~b}$ & $0.19 \mathrm{~b}$ & $0.69 \mathrm{a}$ & $11.3 \mathrm{~b}$ & $60.4 \mathrm{~b}$ & $2.4 \mathrm{a}$ & 6.6 \\
\hline $\mathrm{CV}(\%)$ & 5.7 & 5.7 & 13.6 & 70.9 & 34.6 & 33.0 & 30.6 & 77.3 & 30.8 & 40.1 & 33.1 \\
\hline \multicolumn{12}{|l|}{ Cultivar } \\
\hline IAC 201 & 82.1 & 13.8 & 1.18 & 0.51 & 3.8 & 0.34 & 0.59 & 29.8 & 85.5 & 2.1 & $7.5 \mathrm{a}$ \\
\hline Carajás & 77.9 & 13.1 & 0.97 & 0.52 & 4.5 & 0.33 & 0.49 & 33.1 & 79.4 & 2.0 & $5.9 \mathrm{~b}$ \\
\hline $\mathrm{CV}(\%)$ & 11.1 & 11.2 & 15.3 & 46.6 & 37.3 & 60.8 & 28.7 & 86.8 & 23.9 & 16.4 & 28.7 \\
\hline
\end{tabular}

${ }^{(1)}$ Means followed by different letters in the columns, for each factor, are different by the LSD test $(p \leq 0.05)$. 
Table 6 - Cropping system versus cultivar interaction, partitioned from the analysis of variance for $\mathrm{P}$ content $\left(\mathrm{g} \mathrm{kg}^{-1}\right)$ in polished grains. 1995/96 cropping season.

\begin{tabular}{lcc}
\hline \multirow{2}{*}{ Cropping system } & \multicolumn{2}{c}{ Cultivar } \\
\cline { 2 - 3 } & IAC 201 & Carajás \\
\hline Rainfed & $1.48 \mathrm{aA}^{(1)}$ & $1.07 \mathrm{aB}$ \\
Sprinkler-irrigated & $0.88 \mathrm{bA}$ & $0.88 \mathrm{bA}$ \\
\hline
\end{tabular}

${ }^{(1)}$ Means followed by the same lower case letter in the columns, and upper case letters in the rows are different by the LSD test $(p \leq 0.05)$.

\section{CONCLUSIONS}

For upland rice, sprinkler irrigation increased both milling and head rice yield, especially in years with the occurrence of moisture stress periods during the reproductive and maturation stages. Under lower water availability conditions, the Carajás cultivar presented higher milling yield as compared to cultivar IAC 201. Lower water availability promoted increased protein, $\mathrm{N}, \mathrm{P}, \mathrm{Ca}, \mathrm{Mg}, \mathrm{Fe}$, and $\mathrm{Zn}$ levels and reduced $\mathrm{S}$ and $\mathrm{Cu}$ levels in polished grains. Cultivars IAC 201 and Carajás showed similar nutrient contents in the polished grains.

\section{ACKNOWLEDGEMENTS}

To CNPq for fellowships to the first and second authors.

\section{REFERENCES}

ANGLADETTE, A. El arroz. Barcelona: Editorial Blume, 1969. $867 \mathrm{p}$.

ARF, O.; RODRIGUES, R.A.F.; SÁ, M.E.; CRUSCIOL, C.A.C.; PEREIRA, J.C.R. Preparo do solo, irrigação por aspersão e rendimento de engenho do arroz de terras altas, Scientia Agricola, v.59, p.321-326, 2002.

BARBOSA FILHO, M.P.; FONSECA, J.R. Importância da adubação na qualidade do arroz. In: SÁ, M.E.; BUZETTI, S. (Ed.) Importância da adubação na qualidade dos produtos agrícolas. São Paulo: Ícone, 1994. p.217-231.

BATAGLIA, O.C.; FURLANI, A.M.C.; TEIXEIRA, J.P.F.; FURLANI, P.R.; GALLO, J.R. Métodos de análises químicas de plantas. Campinas: IAC, 1983. 48p.

BAZONI, R.; COSTA; C.A.; ARF, O.; MORAIS, O.P.; SANT'ANA, E.P.; MOURA NETO, F.P.; PITOL, C. Recomendação de cultivares de arroz de sequeiro para o ano agrícola de 1995/96, em Mato Grosso do Sul. Campo Grande: EMPAER, 1995. p.1-5. (Comunicado Técnico, 17).

CASTRO, E.M.; VIEIRA, N.R.A.; RABELO, R.R.; SILVA, S.A. Qualidade de grãos de arroz. Santo Antonio de Goiás: Embrapa Arroz e Feijão, 1999. 30p. (Circular Técnica, 34).
CHEN, Y.L.; KUNZE, O.R. Effect of environmental changes of rice yield and particle size of broken kernels. Cereal Chemistry, v.60, p.238-241, 1983.

CRUSCIOL, C.A.C. Efeito de lâminas de água e da adubação mineral em dois cultivares de arroz-de-sequeiro sob irrigação por aspersão. Botucatu: UNESP/FCA, 1998. 129p. Tese (Doutorado).

CRUSCIOL, C.A.C.; ARF, O.; SORATTO, R.P.; MACHADO, J.R. Qualidade industrial e teores de nutrientes dos grãos do arroz de terras altas sob diferentes lâminas de água e níveis de adubação mineral. Acta Scientiarum. Agronomy, v.25, p.409-415, $2003 \mathrm{a}$.

CRUSCIOL, C.A.C.; ARF, O.; SORATTO, R.P.; MACHADO, J.R. Rendimento de benefício e teores de nutrientes em grãos de arroz de terras altas em função de lâminas de água e adubação mineral. Científica, v.31, p.179-188-2003b.

CRUSCIOL, C.A.C.; MACHADO, J.R.; ARF, O.; RODRIGUES, R.A.F. Rendimento de benefício e de grãos inteiros em função do espaçamento e da densidade de semeadura do arroz de sequeiro. Scientia Agricola, v.56, p.47-52, 1999a.

CRUSCIOL, C.A.C.; MACHADO, J.R.; ARF, O.; RODRIGUES, R.A.F. Rendimento industrial de grãos de arroz irrigado por aspersão em razão do espaçamento entre fileiras e da densidade de semeadura. Científica, v.27, p.165-176, 1999b.

DOORENBOS, J.; PRUITT, W.O. Las necessidades de agua de los cultivos. Roma: FAO, 1976. 194p. (Estudos FAO: Riego e Drenaje, 24).

FREI, M.; BECKER, K. Agro-biodiversity in subsistence-oriented farming systems in a Philippine upland region: nutritional considerations. Biodiversity and Conservation, v.13, p.1591-1610, 2004.

NANDA, J.S.; COFFMAN, W.R. IRRI's efforts to improve the protein content of rice. In: WORKSHOP ON CHEMICAL ASPECTS OF RICE GRAIN QUALITY, 1979, Los Banõs, 1979. Proceedings. Los Banõs: IRRI, 1979. p.33-47.

OLIVEIRA, G.S. Efeito de densidades de semeadura no desenvolvimento de cultivares de arroz (Oryza sativa L.) em condições de sequeiro e irrigado por aspersão. Ilha Solteira: UNESP/FE, 1994. 41p. Monografia (Graduação).

RAIJ, B. van; QUAGGIO, J.A. Métodos de análise de solo para fins de fertilidade. Campinas: Instituto Agronômico, 1983. 31p. (Boletim Técnico, 81).

REICHARDT, K. Relações solo-água-planta para algumas culturas. In: REICHARDT, K. A água em sistemas agrícolas. São Paulo: Manole, 1987. p.157-71.

RODRIGUES, R.A.F. Efeitos do manejo de água nas características fenológicas e produtivas do arroz (Oryza sativa L.) cultivado em condições de sequeiro sob irrigação por aspersão. Botucatu: UNESP/FCA, 1998. 75p. Tese (Doutorado).

SRINIVAS, T.; BHASHYAM, M.K. Effect of variety environment of milling quality of rice. In: INTERNATIONAL RICE RESEARCH INSTITUTE. Rice grain quality and marketing. Manila: IRRI, 1985. p.49-59.

STERMER, R.A. Environmental conditions and stress cracks in milled rice. Cereal Chemistry, v.45, p.365-373, 1968.

YANG, X.; YE, Z.Q.; SHI, C.H.; ZHU, M.L.; GRAHAM, R.D. Genotypic differences in concentrations of iron, manganese, copper, and zinc in polished rice grains. Journal of Plant Nutrition, v.21, p.1453-1462, 1998.

Received April 19, 2006

Accepted April 14, 2008 